\title{
EGYÜTTNEVELÉSI PROGRAM
}

\section{FEHÉRnÉ KovÁCS ZsuZSANNA}

\author{
az Eötvös Loránd Tudományegyetem Bárczi Gusztáv Gyógypedagógiai Kara \\ Fonetikai és Logopédiai Tanszékének \\ föiskolai docense \\ fzsuzsa@barczi.elte.hu
}

Az ELTE Bárczi Gusztáv Gyógypedagógiai Kar egyik programjában elvégzett munkáról „KÖZÉPISKOLÁS FOKON?” című zárókonferencián számolt be az a kari és külső óraadói szakemberekből álló team, amelynek munkáját Papp Gabriella közel egy éven át irányította, ,, A tankötelezettség kiterjesztéséből és az integrációból adódó feladatok" TÁMOP-4.1.2 08/2/B/KMR-2009-0001, alprojekt keretein belül. ${ }^{1}$

A 2011 májusában megrendezett konferencia elsödleges célja azoknak az eredményeknek a bemutatása volt, amelyet a team által kidolgozott együttnevelési program keretein belül az alprogram meg tudott valósítani. Ezek bemutatásával azoknak a lehetőségeknek a körét kívántuk bővíteni, amelyek hozzájárulhatnak a különféle fogyatékossági csoporthoz tartozó, a középiskolai oktatásban integráltan jelen lévő (és leendő) tanulók iskolai sikereinek valósággá válásához. Tudjuk azonban, hogy a célirányos, személyre szabott támogatásukhoz, ezek objektív és szubjektív feltételeinek megismeréséhez, felismeréséhez, megtervezéséhez, létrehozásához még igen sok tenni- és tanulnivalója van az integrációban együttmüködő segítő szakembereknek. A konferencia is ennek érdekében szerveződött.

Az első pár perc meghatározta az egész nap hangulatát, empátiás légkört teremtett azzal a rövid filmbejátszással, amelyet Taara Zameen Par, indiai rendező A föld csillagai (Stars of the Earth) címü, diszlexiás fiúról szóló filmjéből vetítettek. Néhány percig e gyermek szemével láthattuk a betük világát, megélhettük a „táncoló”, mozgó, állandóan változó és ezáltal jelentést nehezen magához vonzó betüket, szavakat és mondatokat. Rácsodálkozhattunk vizuális tüneteire, beleláthattunk gondolkodásába, és néhány percig mi is megélhettük, meg is érthettük ezt a frusztrációt okozó helyzetet, állapotot.

Papp Gabriella bevezető előadása már erre a pozitív légkörre építhetett. Az általa ismertetett programcélkitüzések és eredmények: a létrehozott kutató csoport, a kutatási terv, a tréningalapú továbbképzés, amely két közremüködő középiskola pedagógusainak segítségével (Raoul Wallenberg Humán Szakképző Iskola és Gim-

\footnotetext{
${ }^{1}$ Az elvégzett kutatás leírásáról és a kutatási eredményekről lásd e számunkban Marton Eszter-Papp Gabriella és Perlusz Andrea tanulmányát.
} 
názium, Pesti Barnabás Élelmiszer-ipari Szakképző Iskola és Gimnázium) került kipróbálásra, a filmrészlet segítségével konkrétabbá válhattak a jelenlévők számára. Az előadó beszámolt annak az ELTE Eötvös Kiadónál Középiskolás fokon?! Sajátos nevelési igényü fiatalok együttnevelése a középiskolában címen megjelent tanulmánykötetnek a szerkesztési koncepciójáról is, amelyet a konferencia résztvevői már kezükbe is vehettek. A projekt eredményei így épülhetnek be az ELTE Bárczi Gusztáv Gyógypedagógiai Karának BA és MA képzési tartalmaiba. Sikerként könyvelte el, hogy körvonalazódott a középiskolai együttnevelés protokollja, standardja is. Hangsúlyozta, hogy a rendezvény elsősorban a középiskolai kollégákat kívánta megszólítani, akik számára korszerü pedagógusképzési, továbbképzési koncepciót vázolt fel: önkéntességen, együttmüködésen, tudásépítő és megosztó hálózaton keresztül, kompetenciaalapon, partnerkapcsolati viszonyon alapulót, amely az iskola tanulóközösséggé formálásán keresztül müködik. Meggyőzően érvelve állította, hogy ez az integrációt támogató út elvezethet a tanulás minőségének javulásához, a tantestület folyamatos szakmai fejlödéséhez is.

Marton Eszter (ELTE BGGYK) Honnan indultunk? Az igényfelmérés összesített eredményeinek bemutatása címü előadásában a két részt vevő középiskola pedagógusainak és vezetőinek önkéntesen vállalt kérdőíves kikérdezésének eredményeiről szóló előadása ambivalens érzéseket is keltett. Adataiból egyértelmüen kiderült, hogy mindkét intézmény tanárai, megélt, osztálytermi tapasztalataik alapján, jóval több SNI tanulót feltételeztek iskolájukban, tanítványaik körében, mint ahányan valójában rendelkeznek ilyen szakértői papírral. A kollégák nem ismerték intézményük segítő szakembereit, azok kompetenciáit, azonban határozottan körvonalazták azokat az igényeiket, az SNI diákok fogadásához, amelyek megteremthetnék a szükségletek figyelembe vételén keresztüli támogatás reális esélyeit.

Harmadikként Gavallérné Kancsal Ágnes Az integrációból eredö problémák a Raoul Wallenberg Humán Szakképzö Iskola és Gimnáziumban címmel tartotta meg előadását, a programban részt vevő intézmény képviseletében. Bevezetőjében a középiskola és szakképzés feladatai közötti különbségeket és ennek következményeit helyezte fókuszba: a közismereti és szakmai tanárok arányának változását, illetve e két színtéren elvárt tanulói képességek különbségeire hívta fel a figyelmet. Kérdésként merült fel a hallgatóban, hogy vajon minden esetben figyelembe veszik-e ezeket a különbségeket a középiskolában tanító tanárok. Megtudtuk, hogy az iskola alapító okiratában milyen módon nevesül az integrálandó tanulók köre (jelen esetben: érzékszervi fogyatékosság, testi fogyatékosság, beszédfogyatékosság, valamint a megismerési funkciók vagy a viselkedés fejlődésének organikus okra visszavezethető, illetve arra vissza nem vezethető tartós és súlyos rendellenességével küzdők). Kifejtette, ahhoz, hogy egy középiskola integráló iskolává váljon nem elégséges a törvény adta lehetőség (1993. évi törvény a közoktatásról), az intézménynek figyelembe kell vennie a fenntartója ajánlásait, az iskolaválasztók igényeit és a nevelőtestület integrációhoz való hozzáállását is. Megtudtuk azt az érdekes - szakirodalomnak el- 
lentmondó - adatot is!, hogy a tanulási problémával küzdők aránya (SNI) nem nagyon tért el a középiskolai képzésben és a szakképzésben részt vevők között (1,53\% és 1,21\%). Előadásának legizgalmasabb része $a$,jó integráló " oktató-nevelö intézmény jellemzőinek leirrása volt. Kiemelte, többek között, a támogató környezet fontosságát, a nevelőtestület integrált neveléshez szükséges pedagógiai, pszichológiai képességeit (elfogadás, tolerancia, empátia) és a fejlesztéshez szükséges kompetenciákat. Lényegesnek tartotta még a pedagógusok gazdag módszertani repertoárját, a sikerhez szükséges probléma-megoldási és együttmüködési képességet, a hatékony nevelés és oktatáshoz kapcsolódó folyamatos mérést és visszajelzést, valamint a tárgyi feltételek megteremtését is. Az előadó a megvalósulás akadályát elsősorban a pedagógusok megosztottságában látta: abban, hogy egy részük támogatja e törekvéseket, másik részük viszont teljesen elzárkózik e feladatok elöl, elsősorban a felkészületlenségre hivatkozva. Pontosan ezért hangsúlyozta, hogy az együttnevelésben szerepet vállaló pedagógusoknak meg kellene kapniuk az elvárt segítséget támogatásként. Ezek után megismerhettük azokat a lépéseket, amelyeket ők tettek meg e fejlődés érdekében (a nevelési értekezleteken, a tantárgyi szaktanácsadásban, mentori rendszer kiépítésében, a tanítási segédanyagok beszerzésében, és az érintettek együttmüködésének kialakításában). Egyértelmüvé vált, hogy a fejlödés irányát az oktatást segítők bevonásával tudják elképzelni. Azt sajnos nem tudhattuk meg, hogy ebben az együttmüködésben kinek milyen szerepet szánnának, azaz pontosan hogyan zajlik majd ez a segítő szakemberek, a szaktanárok, a szülö és az érintett diák között.

A negyedik előadást is a Raoul Wallenberg Humán Szakképzö Iskola és Gimnáziumból érkezö tanár, Kremo Márta, tartotta $A$ képzés hatása a mindennapi pedagógiai munkára címmel. E kiváló szakember a pedagógiai munka kihívásai közé sorolta az SNI tanulók integrált támogatását, és előadásában az érdeklődő hallgatók számára egyértelmüsítette is az ehhez szükséges feltételeket és kritériumokat. Mindehhez a hatékony tanulás támogatását társította, egyéni fejlesztési tervbe ágyazta, meghatározta a fejlesztendő kompetenciákat és az ehhez szükséges iskolai segítségnyújtás körét. Példaértékü megközelítésével bemutatta, hogyan lehet a tanulási zavarokat középiskolában is, osztályszinten, integráltan sikeresen „kezelni”.

A szünet utáni első előadásban a Pesti Barnabás Élelmiszeripari Szakképzö Iskola és Gimnázium e rövid idő alatt szerzett tapasztalatait foglalta össze Dobos László és Várhelyi Gabriella, Mit hasznositottunk a tréningböl? címmel.

Ezután az érdeklődő hallgatóság, a szakemberek, gyógypedagógusok, középiskolai tanárok s izgalmas pillanatokat élhettek át. Az Integrációm középfokon címü program során szembe nézhettünk önmagunkkal akkor, amikor egy középiskolát végzett hallássérült fogyatékos diák mesélte el pozitív és negatív iskolai tapasztalatait. Az ő olvasatában hallhattuk milyen tanári attitüdökkel, empátiával, megértéssel és elfogadással találkozott. Reális tükröt tartott elénk, nem szépített. 
Ezt követöen Perlusz Andrea (ELTE BGYGYK) A programeredményesség mérése címen számolt be a két résztvevő intézmény tanárainak kérdőives elégedettségi adatairól. Megtudhattuk, a válaszadók több mint 80 százaléka a tréningen kapott ismereteket megfelelő színvonalúnak ítélte meg, olyannak, amelyek segítették őket a fogyatékossági kategóriák jobb megismerésében. Az előadó további tartalmi elemzései azonban már jóval árnyaltabbá tették ezt a nagyon pozitívnak tünő képet (pl. a túlzott szakmaiság számonkérése vagy a nyújtott ismeretek ellenére a fogyatékossági kategóriák létezésének megkérdőjelezése). Végül egyértelművé vált a hallgatóság számára, hogy az egész képzésröl, a megszerezett ismeretekröl, tapasztalatokról kialakult 75 százalékos pozitív válaszok mögött még ott „lappang” az integrációt teljesen elutasító 25\%-nyi középiskolai tanári arány is, akiket semmiféle ismeret, szaktudás, érzékenyítés, tréning nem tudott megingatni ebben az attitüdjében.

Szekeres Ágota (ELTE BGGYK) a Képzési programmal kapcsolatos további tervekkel ismertette meg a hallgatóságot. Bemutatta a kar három napra kidolgozott tréningalapú érzékenyítő programját: 1 . nap érzékenyítés (a fogyatékossággal kapcsolatos asszociációk megbeszélése, különböző fogyatékossági csoportok rövid bemutatása, szimulációs gyakorlatok), 2. pedagógiai tanácsadás (módszertani és tanulásszervezési segítségnyújtás, a sajátos nevelési igény pszichológiai hátterének feltárása, az elfogadás segítése, team-tanítás), ezt egészíti ki a csoportfeladatos, nyolc lépésből álló mozaik módszer. A 3. nap az esetmegbeszélésé. Mint megtudtuk, a képzés (30 óra) akkreditációja már folyamatban van, amely majd kiegészül egy módszertani gyüjteménnyel is.

A konferencia zárásaként, a program keretén belül megszületett, az ELTE Eötvös Kiadónál 2011-ben, a konferencia napján megjelent Középiskolás fokon?! Sajátos nevelési igényü fiatalok együttnevelése a középiskolákban címü tanulmánykötetet bemutatására került sor. A könyv szerkesztője, egyben az alprogram vezetője is, amint fent már jeleztük, Papp Gabriella, aki ismert gyógypedagógus kutatókat, oktatókat, szerzőket ${ }^{2}$ kért fel, hogy tanulmányban foglalják össze szakterületüknek integrációval kapcsolatos tudását. A kötetet, ezúton szeretnénk olvasóink figyelmébe ajánlani.

Izgalmas szakmai konferencia volt, sok új ismerettel, lehetőséggel. A nem túl nagy létszámú hallgatóság (40-50 fó) soraiban a szorgalmasan jegyzetelő szakemberek között még jóval több volt a téma iránt érdeklődő gyógypedagógus, mint az elkötelezett középiskolai tanár. Tudjuk, ez a TÁMOP alprogram és ez a konferencia is, éppen azért szerveződött, hogy ez az arány a jövőben változzon. Csak remélni tudjuk, hogy elindultunk ezen az úton.

\footnotetext{
${ }^{2}$ A kötetben való megjelenés sorrendjében: Papp Gabriella, Marton Eszter, Schiffer Csilla, Radványi Katalin, Perlusz Andrea, Vargáné Mezö Lilla, Fehérné Kovács Zsuzsa, Takács István, Fótiné Hoffmann Éva, Lénárt Zoltán, Minkó Renáta, Szekeres Ágota.
} 